Available online at GSC Online Press Directory

GSC Biological and Pharmaceutical Sciences

e-ISSN: 2581-3250, CODEN (USA): GBPSC2

Journal homepage: https://www.gsconlinepress.com/journals/gscbps

(RESEARCH ARTICLE)

\title{
Dietary supplementation with manganese and selenium offer protection against cadmium-induced oxidative damage to rat liver and kidney
}

\author{
Simon Gabriel Mafulul 1, ${ }^{*}$, Enoch Banbilbwa Joel ${ }^{1}$, Chukwudi Acha Orji ${ }^{1}$, Comfort Sokomba Edah ${ }^{1}$, Larry \\ Auta Barde ${ }^{2}$ and Francis Obiora Okonkwo ${ }^{2}$ \\ ${ }_{1}^{1}$ Department of Biochemistry, Faculty of Basic Medical Sciences, University of Jos, Jos, Plateau State, Nigeria. \\ ${ }^{2}$ Department of Biochemistry, Faculty of Natural and Applied Sciences, Plateau State University, Bokkos, Plateau State, \\ Nigeria.
}

Publication history: Received on 08 October 2020; revised on 19 October 2020; accepted on 24 October 2020

Article DOI: https://doi.org/10.30574/gscbps.2020.13.1.0339

\begin{abstract}
The present study determined the effect of pre-supplementation with manganese (Mn) and selenium (Se) on biomarkers of oxidative stress in the liver and kidneys of rats exposed to a mild dose of cadmium. Sixteen Male Wistar strain rats (180-200 g b. wt) were divided into four groups (control, Cd alone, $\mathrm{Mn}+\mathrm{Se}+\mathrm{Cd}$ and $\mathrm{Mn}+\mathrm{Se}$ ). The rats used as the control received a normal rat diet and tap water throughout the study while the Cd alone rats received a normal rat diet and then exposed to a single daily oral dose of cadmium ( $3 \mathrm{mg} \mathrm{CdCl} 2 / \mathrm{kg}$ ) in drinking water for three days. Mn $+\mathrm{Se}+\mathrm{Cd}$ rats were pretreated with $\mathrm{Mn}\left(3 \mathrm{mg} \mathrm{MnCl}_{2} / \mathrm{kg} /\right.$ day $)$ and Se $(3 \mathrm{mg} \mathrm{SeO} / 2 / \mathrm{kg} /$ day) for seven days and thereafter received a single daily oral dose of cadmium $\left(3 \mathrm{mg} \mathrm{CdCl}_{2} / \mathrm{kg}\right)$ in drinking water for three days while Mn + Se rats were exposed to only $\mathrm{Mn}\left(3 \mathrm{mg} \mathrm{MnCl} / \mathrm{kg} /\right.$ day) and Se ( $3 \mathrm{mg} \mathrm{SeO}_{2} / \mathrm{kg} /$ day) for seven days. At the end of the experiment tissue cadmium concentration, membrane lipid peroxidation, glutathione content, and activities of antioxidant enzymes catalase, superoxide dismutase, and glutathione peroxidase were determined in the liver and kidney samples. The results showed that pretreatment with $\mathrm{Mn}$ and Se effectively countered Cd-induced cadmium accumulation, membrane lipid peroxidation, depletion of the non-enzymic antioxidant, glutathione, and induction of the antioxidant enzymes catalase, superoxide dismutase and glutathione peroxidase in the liver and kidney. It can be concluded that presupplementation with $\mathrm{Mn}$ and Se significantly reversed $\mathrm{Cd}$-induced deleterious alterations in the liver and kidney tissue of the rats.
\end{abstract}

Keywords: Cadmium; Selenium; Manganese; Pre-supplementation; Antioxidants; lipid peroxidation

\section{Introduction}

Cadmium is a well-known industrial and environmental pollutant that is released into the environment from anthropogenic activities such as metal mining and processing [1].Its use in various industrial processes such as the battery, plastics, pigment, and fertilizer production and electroplating has further increased its incidence in the environment leading to contamination of soil and water and subsequent uptake by food crops grown on contaminated soil or water [2]. Human exposure to environmental cadmium pollutants is mainly through inhalation of contaminated air and the oral route through the food chain with the latter being the major route of exposure [3]. Following gastrointestinal absorption, the cadmium-binding protein, metallothionein, rapidly take up cadmium from the blood and delivers it first to the liver and from the liver, it is then rapidly redistributed to other tissues and organs of the body[4].Within the human body, cadmium has a long biological half-life of up to 30 years and a low excretion rate leading to its bio-accumulation to toxic levels in the liver and kidneys and other soft tissues of the body causing

${ }^{*}$ Corresponding author: Simon Gabriel Mafulul

Department of Biochemistry, Faculty of Basic Medical Sciences, University of Jos, Jos, Plateau State, Nigeria.

Copyright $(2020$ Author(s) retain the copyright of this article. This article is published under the terms of the Creative Commons Attribution Liscense 4.0. 
membrane lipid peroxidation and oxidative deterioration of proteins and DNA and in the process initiates various pathological conditions [5].

Furthermore, studies with experimental animals have shown that chronic exposure to cadmium through contaminated soil, water, air, and the food chain leads to many diseases including cancer [6]. Epidemiological evidence linking $\mathrm{Cd}$ contaminated food sources to the outbreak of itai itai disease which occurred in the Cd-polluted Jinzu River basin in Toyama, Japan awakened public health interest to the toxic effects of environmental exposure to Cd and its effects on human health [7]. Itai itai disease is the most severe stage of chronic Cd poisoning and it is characterized by, among others, severe bone disorders and renal tubular lesions $[7,8]$.

It has been demonstrated that several antioxidants and antioxidant defense systems have been shown to protect cells of target organs from Cd toxicity or reverse Cd toxicity $[9,10]$. Manganese (Mn) and Selenium (Se) are essential trace elements required in living organisms both as activators and constituents of antioxidant enzymes [11-13]. Manganese is an important cofactor of mitochondrial superoxide dismutase while selenium is an essential component of glutathione peroxidase which detoxifies peroxides and hydroperoxides [11,14]. These antioxidant enzymes scavenge oxygen free radicals which cause oxidative stress by membrane lipid peroxidation $[14,15]$. It has been reported separately that Manganese (Mn) and Selenium (Se) offer protective action against oxidative stress-mediated Cd toxicity from studies involving Manganese and Selenium [12, 16]. However, other possible forms of exposure that combine the effect of manganese and selenium appear not to have been appraised. Thus, in this study, we have examined the combined effect of pre-supplementation with $\mathrm{Mn}$ and Se on short term exposure to a mild dose of $\mathrm{Cd}$ as determined by the level of the pattern of tissue $\mathrm{Cd}$ bioaccumulation, membrane lipid peroxidation, and activity of the antioxidant defense system in the hepatic and renal tissues of rats.

\section{Material andmethods}

\subsection{Animal treatment}

Wistar Strain male rats (b.wt. 180-200 g) purchased from the Animal House Unit, University of Jos, were used in the study. They were allowed free access to a standard rat diet, 'Vital Feed' (purchased from Grand Cereals and Oil Mills Ltd, Kuru, Nigeria) and tap water as drinking water, ad libitum. The respective working doses of $\mathrm{Se}\left(\mathrm{as} \mathrm{SeO}_{2}\right)$, and $\mathrm{Cd}$ (as $\mathrm{CdCl}_{2}$ ) administered orally to experimental animals in this study were obtained from our previous study [17] while that of $\mathrm{Mn}\left(\mathrm{as} \mathrm{MnCl}_{2}\right.$ ) was first determined in a pilot study.

Rats were weighed and evenly distributed into four groups (control, $\mathrm{Cd}$ alone, $\mathrm{Mn}+\mathrm{Se}+\mathrm{Cd}$ and $\mathrm{Mn}+\mathrm{Se}$ ) with each group consisting of 4 rats. All the rats in the four groups were allowed free access to the standard 'Vital feed' rat diet and drinking water ad libitum throughout the experiment. The control rats received only rat diet and drinking water while each rat in the $\mathrm{Mn}+\mathrm{Se}+\mathrm{Cd}$ and $\mathrm{Mn}+$ Se groups received twice daily, an oral supplement of $\mathrm{Mn}(3.0 \mathrm{mg} \mathrm{MnCl} / \mathrm{kg}$ b.wt) and $\mathrm{Se}\left(3.0 \mathrm{mg} \mathrm{SeO} / \mathrm{kg}\right.$ b.wt/day), as aqueous solutions of $\mathrm{MnCl} 2$ and $\mathrm{SeO}_{2}$ respectively, administered employing a needle-free Syringe for a period of 7days. Thereafter, rats in the $\mathrm{Cd}$ alone and $\mathrm{Mn}+\mathrm{Se}+\mathrm{Cd}$ groups were each given one single oral dose of $\mathrm{CdCl}_{2}$ in aqueous solution $(3 \mathrm{mg} \mathrm{CdCl} / 2 \mathrm{~kg}$ b.wt) daily for 3 days.

\subsection{Tissue collection and preparation}

At the end of the feeding experiment, on day 11, rats under anesthesia were sacrificed by decapitation and, in each case, the liver and kidneys were excised and washed in ice-cold normal saline to remove adhering blood particles. Homogenates of liver and kidney samples of each rat were prepared separately by homogenizing $1 \mathrm{~g}$ portion in ice-cold 50 mMTris-HCl buffer, pH7.4 (1:10, w/v) using a homogenizer. The homogenates of the liver and kidney tissues were centrifuged at 2,400 $\mathrm{xg}$ for 10 minutes in a refrigerated low-speed centrifuge and the supernatant fractions were collected with Pasteur Pipette into plastic vials and stored at $2{ }^{\circ} \mathrm{C}$ pending biochemical analysis. The rest of the kidney and liver samples were used for the determination of $\mathrm{Cd}$ content.

\subsection{Tissue cadmium determination}

The liver and kidney cadmium concentration were analyzed using inductively coupled plasma optical emission spectrophotometer (ICP OES) optima 2000DV after wet digestion. One gram portion of the tissue was digested with 20 $\mathrm{ml} \mathrm{HNO} 3-\mathrm{HCLO}_{4}$ mixture $(1: 4 \mathrm{v} / \mathrm{v})$ at $100{ }^{\circ} \mathrm{C}$ and the resultant digest diluted to $100 \mathrm{ml}$ with deionized water [18]. 


\subsection{Determination of lipid peroxidation}

Lipid peroxidation in the liver and kidney homogenates was determined by measuring the concentration of malondialdehyde (MDA) as thiobarbituric acid reactive substance as described by Ohkawa et al. [19]. The reaction was started by mixing $0.4 \mathrm{ml}$ of tissue homogenate with $1.6 \mathrm{ml}$ of $50 \mathrm{mMTris}-\mathrm{KCl}$ buffer and then $0.5 \mathrm{ml}$ each of $30 \%$ trichloroacetic acid (TCA) and $0.75 \%$ thiobarbituric acid (TBA) was added and the reaction mixture was incubated in a water bath at $80^{\circ} \mathrm{C}$ for 15 minutes. Thereafter, the mixture was cooled and centrifuged at $24000 \mathrm{~g}$ for 10 minutes. The absorbance of the tissue supernatants was read at $532 \mathrm{~nm}$ in a $650 \mathrm{UV}$ spectrophotometer. The detected MDA as a marker of lipid peroxidation in units/mg protein was estimated using the molar extinction coefficient at $532 \mathrm{~nm}$ of 1.56 $\mathrm{x} 10^{5} \mathrm{M}^{-1} \mathrm{~cm}^{-1}$.

$$
M D A\left(\frac{\text { units }}{\text { mg protein }}\right)=\frac{\text { Absorbance } \mathrm{x} \text { volume of the mixture }}{\text { Molar extinction coefficient } \mathrm{x} \text { volume of sample } \mathrm{x} \mathrm{mg}}
$$

\subsection{Determination of catalase (EC: 1.11.1.6)}

Catalase (CAT) (EC1.11.1.6) activity in the liver and kidney homogenates was determined by assaying the rate of decomposition of hydrogen peroxide as described by Aebi [20]. The enzyme assay totaling 1 ml was constituted with $100 \mathrm{mM}$ phosphate buffer ( $\mathrm{pH} 7.0$ ), $0.1 \mathrm{mM}$ EDTA, $0.1 \% \mathrm{H}_{2} \mathrm{O}_{2}$, and $100 \mu \mathrm{L}$ enzyme extract. The decrease of $\mathrm{H}_{2} \mathrm{O}_{2}$ was monitored at $240 \mathrm{~nm}$ and quantified by its molar extinction coefficient $\left(\varepsilon=39.4 \mathrm{mM}^{-1} \mathrm{~cm}^{-1}\right)$. CAT activity was expressed as $\mathrm{Umg}^{-1}$ protein. The concentration of the enzyme required to breakdown one $\mu$ mol of $\mathrm{H}_{2} \mathrm{O}_{2}$ per minute is referred to as one unit of CAT activity.

\subsection{Determination of superoxide dismutase (EC1.15.1.1)}

The activity of the antioxidant enzyme, superoxide dismutase (SOD) was determined by its ability to inhibit the autooxidation of epinephrine as described by Misra and Fridovich [21]. The assay procedure began with the addition of an aliquot of the sample to $2.5 \mathrm{ml}$ of $0.05 \mathrm{M}$ carbonate buffer ( $\mathrm{pH} 10.2$ ) which was allowed to equilibrate in the spectrophotometer. The reaction was initiated by the addition of $0.3 \mathrm{ml}$ of freshly prepared $0.3 \mathrm{mM}$ adrenaline to the mixture which was quickly mixed by inversion. Thereafter, the increase in absorbance at $480 \mathrm{~nm}$ due to the formation of the product of the reaction, adrenochrome, was monitored every 30 seconds for 150 seconds. The overall reaction mixture consists of $2.5 \mathrm{ml}$ buffer, $0.3 \mathrm{ml}$ of the substrate (adrenaline), and $0.2 \mathrm{ml}$ of water. The concentration of SOD necessary to cause $50 \%$ inhibition of the oxidation of epinephrine to adrenochrome during the 150 seconds defines one unit of SOD activity.

\section{Calculation:}

Increase in Absorbance per minute $=\left(\mathrm{A}_{3}-\mathrm{A}_{0}\right) / 2.5$

Where; $A_{0}=$ absorbance after 30 seconds and

$\mathrm{A}_{3}=$ absorbance after 150 seconds.

$\%$ Inhibition $=\underline{\text { Increase in absorbance of substrate }} \times 100$

Increase in absorbance of blank

\subsection{Determination of glutathione peroxidase (EC: 1.11.1.9)}

The assay of glutathione peroxidase (GPx) activity based on the principle of oxidation of GSH to GSSG was measured spectrophotometrically using the procedure described by Paglia and Valentine [22]. The reaction mixture contained $50 \mathrm{mM}$ potassium phosphate buffer ( $\mathrm{pH} 7.0$ ), 1mM Ethylenediaminetetraacetic Acid (EDTA), $1 \mathrm{mM}$ sodium azide, 0.2 mM ß-Nicotinamide Adenine Dinucleotide Phosphate, Reduced Form (ß-NADPH), 1 U glutathione reductase and 1 mM reduced glutathione. After the addition of the sample, the reaction was allowed to equilibrate for 5 minutes at $25^{\circ} \mathrm{C}$. Thereafter, the reaction was initiated by the addition of $0.1 \mathrm{ml}$ of $2.5 \mathrm{mM}$ hydrogen peroxide and the rate of NADPH oxidation to $\mathrm{NADP}^{+}$was measured at $340 \mathrm{~nm}$ for 5 minutes. Glutathione peroxidase activity was expressed as nmol of $\mathrm{NADPH}$ consumed $/ \mathrm{min} / \mathrm{mg}$ protein using the extinction coefficient of $6.2 \times 10^{3} \mathrm{M}^{-1} \mathrm{~cm}^{-1}$ at $340 \mathrm{~nm}$. 


\subsection{Statistical analysis}

All statistical analyses were carried out with GraphPad Prism 4.02 for Windows (GraphPad Software, San Diego, CA). Significant differences between treatment effects were done using one way ANOVA, followed by Tukey's posthoc test for multiple comparisons, and statistical significance was considered at $p<0.05$. Results were expressed as mean \pm standard deviation (mean \pm SD) and the number of replications (n) in figures denotes individual rats measured for each parameter in each group.

\section{Results}

\subsection{Liver and kidney cadmium concentration}

The results of liver and kidney cadmium determination are summarized in Figure 1. Cadmium was detected in the liver and kidney of both the control and treated rats. However, the mean Cd concentration in the liver and kidney of rats exposed to Cd alone was significantly $(\mathrm{p}<0.05)$ higher than in the corresponding tissues of control rats and those treated with $\mathrm{Mn}$ and Se. The liver and kidney of rats exposed to Cd following 7days pre-supplementation with Mn and Se had a significantly lower $(\mathrm{p}<0.05) \mathrm{Cd}$ concentration than the corresponding tissues of rats exposed to Cd alone. Whereas, the liver and kidney of rats pre-supplemented with $\mathrm{Mn}$ and Se alone had a significantly lower $(\mathrm{p}<0.05) \mathrm{Cd}$ concentration than both the control and rats exposed to $\mathrm{Cd}$ alone. This suggests that pretreatment with Mn and Se protected against bioaccumulation of $\mathrm{Cd}$. Generally, the mean Cd concentration in the kidney tissue was significantly higher $(\mathrm{p}<0.05)$ than that of the liver indicating that the kidney was more active in bioaccumulation of Cd than the liver.

\section{C d}

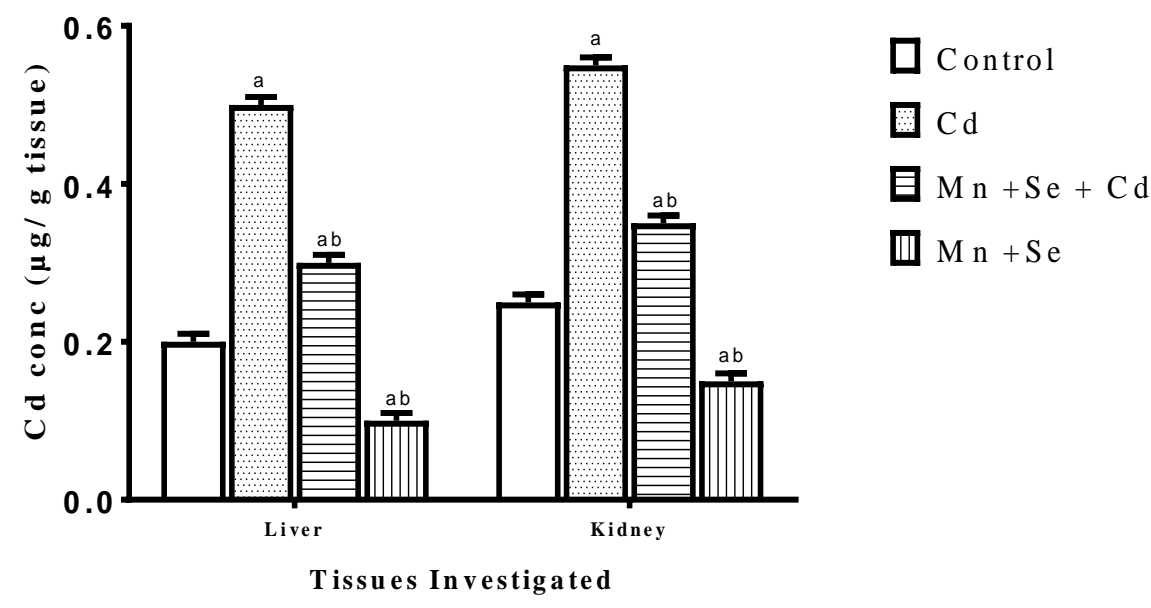

Figure 1 Effect of pre-supplementation with $\mathrm{Mn}$ and Se on cadmium concentration of rat liver and kidneys. Results are expressed as Mean $\pm \mathrm{SD}(\mathrm{n}=4) \mathrm{Cd}$ concentration $(\mu \mathrm{g} / \mathrm{g}$ tissue); a-values are significantly different from control $(\mathrm{p}<0.05)$; $\mathrm{b}$-values are significantly different from the group treated with Cd alone $(\mathrm{p}<0.05)$

\subsection{Membrane lipid peroxidation}

The results of the assay of membrane lipid peroxidation determined as malondialdehyde (MDA) are summarized in Figure 2. The concentration of MDA in the liver and kidney of rats exposed to $\mathrm{Cd}$ alone was significantly higher ( $\mathrm{p}<0.05$ ) than in the corresponding tissues of the control and rats pre-supplemented with Mn and Se. However, presupplementation with $\mathrm{Mn}$ and Se before Cd administration in the liver and kidney significantly decreased (p<0.05) MDA concentration in the corresponding tissues of rats. Furthermore, the liver and kidney of rats pre-supplemented with Mn and Se alone had a significantly lower $(\mathrm{p}<0.05)$ MDA concentration than both the control and rats exposed to Cd alone and Cd pre-supplemented with $\mathrm{Mn}$ and Se. This suggests that pretreatment with $\mathrm{Mn}$ and Se protected against Cdinduced membrane lipid peroxidation. Generally, the mean MDA concentration in the kidney tissue was significantly higher $(\mathrm{p}<0.05)$ than that of the liver indicating that the kidney was more prone to Cd-induced membrane lipid peroxidation than the liver. 
M D A

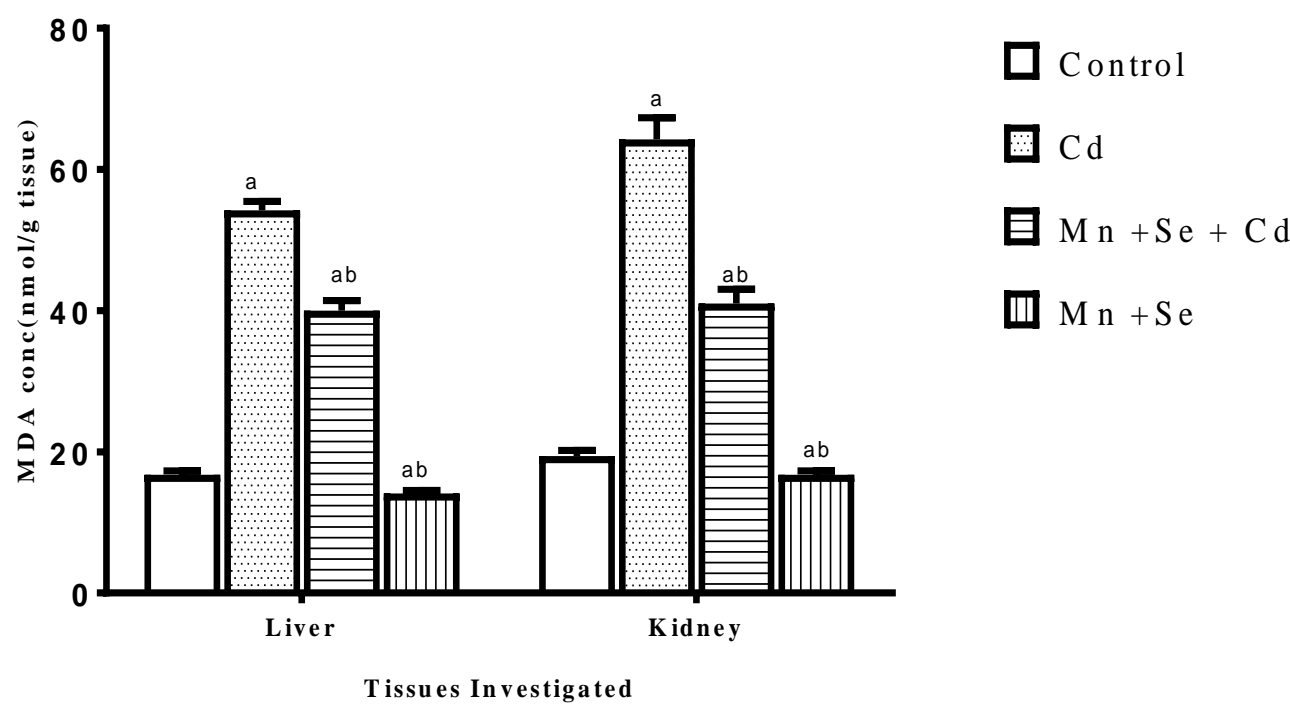

Figure 2 Effect of pre-supplementation with Mn and Se on cadmium-induced lipid peroxidation in rat liver and kidneys.

Results are expressed as Mean $\pm \mathrm{SD}(\mathrm{n}=4) \mathrm{MDA}$ concentration (nmol/g tissue); a-values are significantly different from control ( $\mathrm{p}<0.05)$; $\mathrm{b}$-values are significantly different from the group treated with Cd alone $(\mathrm{p}<0.05)$

\subsection{Non-enzymic tissue antioxidant, glutathione}

The results of tissue glutathione determinations are summarized in Figure 3. The concentration of glutathione was significantly lower in the liver and kidney of rats exposed to $\mathrm{Cd}$ alone when compared to the corresponding tissue of the control rats indicating that exposure to Cd markedly depleted glutathione stores of the liver and kidney. However, pretreatment with $\mathrm{Mn}$ and Se before Cd exposure significantly increased glutathione concentration in the liver and kidney when compared to the corresponding tissues of rats exposed to $\mathrm{Cd}$ alone. This indicates that presupplementation with $\mathrm{Mn}$ and Se before Cd exposure inhibited glutathione depletion by Cd. Furthermore, the liver and kidney of rats pre-supplemented with $\mathrm{Mn}$ and Se alone had a significantly higher $(\mathrm{p}<0.05)$ glutathione concentration than the control suggesting that pretreatment with Mn and Se busted antioxidant capacity of glutathione in the tissues. Generally, the mean glutathione content of the liver is higher than that of the kidney, suggesting that the liver has higher glutathione reserves than the kidney.

\section{GSH}
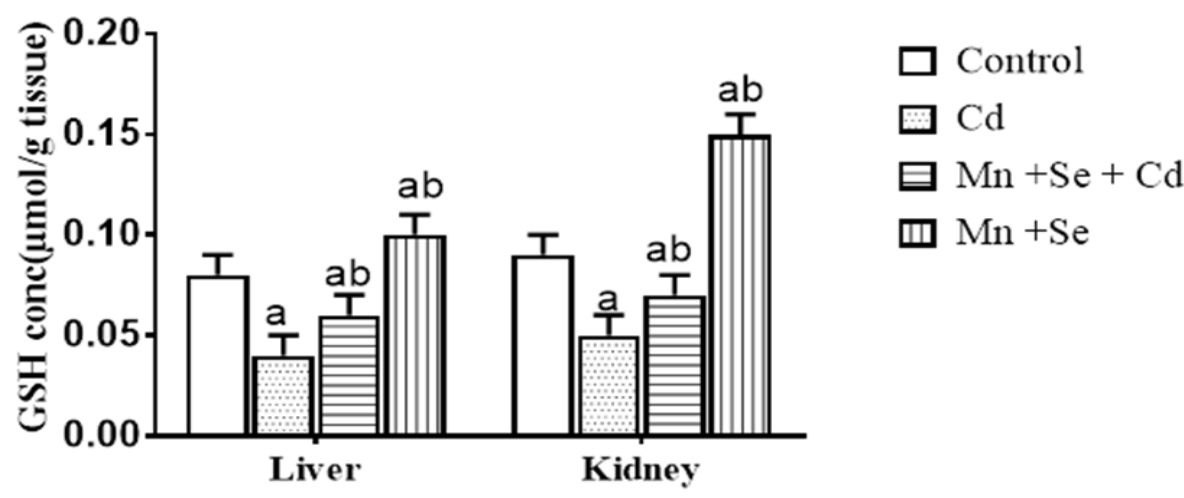

Tissues Investigated

Figure 3 Effect of pre-supplementation with $\mathrm{Mn}$ and Se on tissue glutathione content of rats exposed to Cd. Results are expressed as Mean $\pm S D(n=4)$ glutathione concentration ( $\mu \mathrm{mol} / \mathrm{g}$ tissue); $\mathrm{a}$ - values are significantly different from control ( $\mathrm{p}<0.05)$; $\mathrm{b}$ values are significantly different from the group treated with $\mathrm{Cd}$ alone $(\mathrm{p}<0.05)$ 


\subsection{Antioxidant enzymes}

The results of the activities of antioxidant enzymes catalase, superoxide dismutase, and glutathione peroxidase in the liver and kidney are summarized in Figures 4, 5, and 6 respectively. The mean activity of each of the antioxidant enzymes (CAT, SOD, and GPx) in the liver and kidney were significantly higher $(\mathrm{p}<0.05)$ in rats exposed to cadmium alone when compared to the corresponding tissues of control rats suggesting that exposure to cadmium-induced the activities of these antioxidant enzymes in the liver and kidney. However, pretreatment with Mn and Se before Cd exposure significantly decreased the antioxidant enzyme-inducing effect of cadmium on CAT (Figure 4), SOD (Figure 5), and GPx (Figure 6) in the liver and kidney. Furthermore, the liver and kidney of rats pre-supplemented with Mn and Se alone had significantly lower $(\mathrm{p}<0.05)$ activities of antioxidant enzymes than the control suggesting that pretreatment with $\mathrm{Mn}$ and Se inhibited induction of these antioxidant enzymes.

\section{CAT}

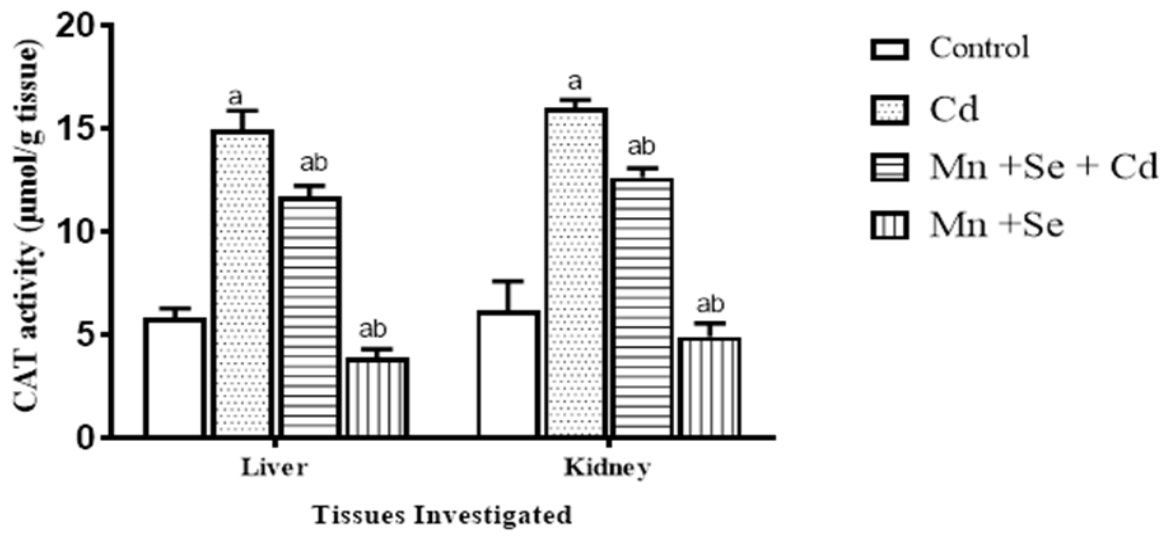

Figure 4 Effect of pre-supplementation with $\mathrm{Mn}$ and Se on CAT activity in the liver and kidneys of rats exposed to Cd. Results are expressed as Mean $\pm S D(n=4)$ CAT activity ( $\mu \mathrm{mol} / g$ tissue); a-values are significantly different from control $(p<0.05) ; b$-values are significantly different from the group treated with Cd alone $(\mathrm{p}<0.05)$

\section{SOD}



Figure 5 Effect of pre-supplementation with Mn and Se on SOD activity in the liver and kidneys of rats exposed to Cd. Results are expressed as Mean $\pm S D(n=4)$ SOD activity (unit/g tissue); a-values are significantly different from control $(p<0.05) ; b$-values are significantly different from the group treated with $\mathrm{Cd}$ alone $(\mathrm{p}<0.05)$ 
GPx

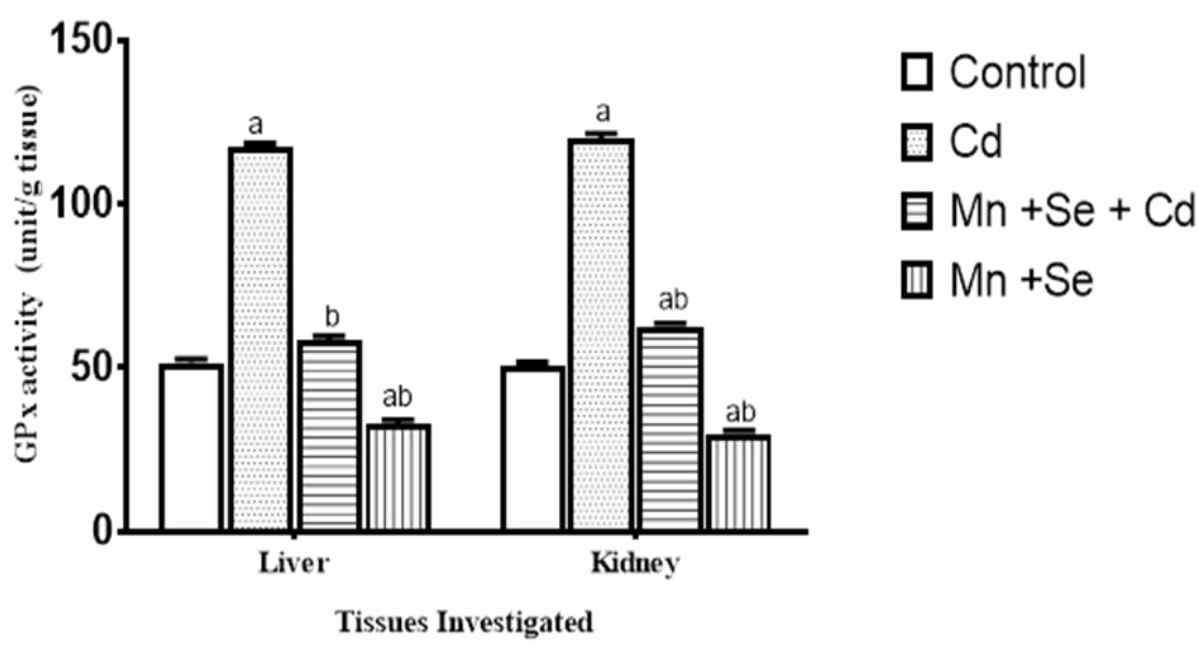

Figure 6 Effect of pre-supplementation with Mn and Se on GPx activity in the liver and kidneys of rats exposed to Cd. Results are expressed as Mean $\pm S D(n=4)$ GPxactivity (unit/g tissue); a-values are significantly different from control $(\mathrm{p}<0.05)$; $b$-values are significantly different from the group treated with Cd alone $(\mathrm{p}<0.05)$.

\section{Discussion}

This study was performed to investigate the effect of pre-supplementation with manganese and selenium on exposure to mild concentrations of cadmium in experimental animals. Cd bioaccumulation was analyzed in the liver and kidney of control and Cd treated male albino rats and our results showed that rats intoxicated with Cd bioaccumulated high levels of the metal in their liver and kidney tissues than the control but pre-supplementation with Mn and Se markedly reduced the level of bioaccumulation of $\mathrm{Cd}$ in the rat liver and kidney reflecting a protective effect of $\mathrm{Mn}$ and Se against $\mathrm{Cd}$ bioaccumulation. This is in agreement with the previous studies which showed that oral intake of cadmium induces its accumulation in these tissues [17]. The occurrence of small concentration of cadmium in the liver and kidney of rats on the control diets has similarly been reported by previous workers $[17,18,23]$. This indeed is a reflection of the ubiquity of cadmium in the food chain and the environment suggesting that the rats feeding environment may have been contaminated by cadmium. The exact mechanism of $\mathrm{Cd}$ toxicity is not known but various reports are indicating that $\mathrm{Cd}$ manifests its toxicity in humans and animals mainly through bioaccumulation in target tissues, stimulation of the generation of free radicals and interference with the utilization of essential metals, all of which culminate in oxidative stress [24-26]. On bioaccumulation, $\mathrm{Cd}$ can bind or combines with thiol or sulphydryl groups of several biological proteins and endogenous antioxidant enzymes and form complexes with them leading to its bioaccumulation in the tissue [27]. Cadmium can also replace and interfere with the utilization of essential micronutrient trace metals in biological systems from various cytoplasmic and membrane proteins as well as essential metals transporter proteins, thus increasing the pool of free metal ions in many biological systems [28]. This leads to disruption of the conformation of these proteins leading to inactivation of their associated biological function as well as the generation of free radicals that attack membrane lipid and other biomolecules culminating in oxidative stress. However, pre-supplementation with $\mathrm{Mn}$ and Se before exposure to cadmium exposure is believed to ameliorate the cadmium-induced oxidative stress in the tissues through the formation of cadmium-manganese and cadmium-selenium complexes which help in removal or reduction of cadmium burden from various biological systems and thereby making the affected organs or tissues free from cadmium burden or by interfering with free radical chain initiation and progression of Cd-induced oxidative damage.

Membrane lipid peroxidation is considered as one of the early manifestations of oxidative damage to tissues such as the liver and kidney and through the generation of MDA it has been shown to play important role in the toxicity of cadmium in animals and humans [5,29-31]. Our findings confirm that exposure to cadmium causes a significant increase in membrane lipid peroxidation in the liver and kidney and pre-supplementation with $\mathrm{Mn}$ and Se significantly reduced the level of Cd-induced membrane lipid peroxidation products in the tissues. This is in agreement with reported protective effects of antioxidant nutrients against Cd-induced lipid peroxidation in the liver and kidney [32]. It is believed that exposure to Cd causes tissue damage due to excessive formation of free such as ROS leading to oxidative stress which overwhelms the antioxidant defense systems of the body leading to the deterioration of biological membrane lipids which in turn leads to increased lipid peroxidation. Many researchers have also reported an increased level of lipid 
peroxidation in various tissues of Cd treated rats [30,33,34]. The observed decrease in the level of lipid peroxidation in the Cd intoxicated rats pre-supplementated with $\mathrm{Mn}$ and Se may be due to the excellent antioxidant activity of these micronutrients which have been recognized to scavenge free radicals thereby inhibiting lipid peroxidation [30]. It was reported that ROS may propagate the initial attack on lipid membranes to cause lipid peroxidation [5,31]. The extent of reduction of $\mathrm{Cd}$-induced lipid peroxidation by $\mathrm{Mn}$ and Se pre-supplementation was highest in the liver than in the kidney.

Glutathione is a naturally occurring endogenous nonenzymatic antioxidant which functions in the cellular defense mechanism of the body against various toxicants including heavy metals $[10,35]$. Our study found that exposure to cadmium-induced a significant depletion of glutathione in the rat liver and kidney but pre-supplementation with Mn and Se effectively prevented the tissue depletion of glutathione reserves. The observed sparing effect of Mn and Se presupplementation on Cd-induced depletion of the endogenous nonenzymatic antioxidant, glutathione is in agreement with our previous findings that exposure to Cd caused a marked decrease in the concentration of glutathione in the rat liver and kidney which was increased in antioxidant supplementation [17,36]. Furthermore, other researchers have also reported a decrease in glutathione levels in the liver and kidney which was increased with antioxidant supplementation [23]. The underlying mechanism of glutathione action in the tissues involves the removal of free radicals such as $\mathrm{H} 2 \mathrm{O} 2$ and superoxide anions, maintenance of membrane protein thiols groups, and acting as a substrate for antioxidant enzymes [37,38]. A recent study reported that GSH forms the first line of defense against oxidative stress, by direct interaction of its thiol group with ROS and/or it can be involved in the enzymatic detoxification reaction of ROS as a cofactor or as a coenzyme [38].

On antioxidants, the three primary endogenous antioxidant enzymes that constitute a mutually supportive first line of defense systems for the removal of reactive oxygen species and protection of cells, tissues, and organs from oxidative damage are catalase (CAT), superoxide dismutase (SOD)and glutathione peroxidase (GPx) [25,30,39]. Our results have shown that exposure to cadmium significantly increased CAT, SOD, and GPx levels in the liver and kidney of Cd intoxicated rats which was effectively reduced by pre-supplementation with $\mathrm{Mn}$ and Se. The observed decrease in the antioxidant enzyme level in Mn and Se pre-supplementation is in agreement with our previous studies which reported that exposure to a mild concentration of $\mathrm{Cd}$ caused a marked increase in the concentration of antioxidant enzymes which was reversed by antioxidant pretreatment $[17,36]$. Some researchers have also reported similar increases in the concentration of antioxidant enzymes in the liver and kidney [40] while others' results are at variance with our findings and reported a decrease in the activity of antioxidant enzymes in the liver and kidneys of rats treated with Cd $[18,23,41]$.The increase in CAT, SOD, and GPx activities may be interpreted as a protective response against cadmium toxicity; that is enzyme levels increases as a protective mechanism [40]. Studies have also shown that when cells are exposed to many xenobiotics and prooxidants, enzymes responsible for their metabolism are induced [42]. Indeed, it has been shown that the activity of antioxidant enzymes behaves in two different ways during oxidative stress [40]. At the beginning of stress, this activity increases, while in the long term, it is reduced due to the massive production of free radicals. This reduction is the result of damage to the molecular machinery that is required to induce these enzymes [40]. The apparent contradiction between these reports and our present findings is traceable to the difference in the oral dose of $\mathrm{Cd}$ and duration of exposure. As our cadmium dose $(3 \mathrm{mg} / \mathrm{kg})$ for a three-day Cd exposure is relatively mild compared to other workers Cd doses of $15 \mathrm{mg} \mathrm{Cd} / \mathrm{kg}$ for four weeks [23] and $100 \mathrm{mg} \mathrm{Cd} / \mathrm{kg}$ for 16 weeks [18]

\section{Conclusion}

It can be concluded from the findings of this study that Mn and Se pre-supplementation offers protection against Cdinduced oxidative damage to tissues as determined by tissue $\mathrm{Cd}$ disposition system, membrane lipid peroxidation, and the antioxidant defense system.

\section{Compliance with ethical standards}

\section{Acknowledgments}

The authors acknowledge the contribution and advice of staff Animal House and laboratory technologists of the Department of Biochemistry, Faculty of Basic Medical Sciences, College of Health Sciences, University of Jos, Jos.

\section{Disclosure of conflict of interest}

There is no conflict of interest among all authors. 


\section{Statement of ethical approval}

This research was carried out according to the ethical standards for the care and use of laboratory animal experimentation reviewed in NIH publication no. 8523, revised 1985. The ethical clearance and approval for this research was obtained from the Animal Research Ethics Committee of the Faculty of Pharmaceutical Sciences, University of Jos, Jos, Nigeria with approval number UJ/FPS/F17-00379.

\section{References}

[1] Ali H, Khan E, Ilahi I. Environmental chemistry and ecotoxicology of hazardous heavy metals: Environmental persistence, toxicity, and bioaccumulation. Journal of Chemistry. 2019.

[2] Schaefer HR, Dennis S, Fitzpatrick S. Cadmium : Mitigation strategies to reduce dietary exposure, Journal of Food Science, 2020; 85(2): 260-267.

[3] Arroyo VS, Flores KM, Ortiz LB, Gómez-quiroz LE, Gutiérrez-ruiz MC. Liver and cadmium toxicity. Journal of Drug Metabolism \& Toxicology. 2012;1-7.

[4] Asagba So. Role of diet in absorption and toxicity of oral cadmium- A review of literature. African Journal of Biotechnology, 2009; 8(25):7428-7436.

[5] Waisberg M, Joseph P, Hale B, Beyersmann D. Molecular and cellular mechanisms of cadmium carcinogenesis. Toxicology. 2003; 192: 95-117.

[6] Rahimzadeh MR, Rahimzadeh MR, Kazemi S, Moghadamnia AA. Cadmium toxicity and treatment: An update. Caspian Journal of Internal Medicine. 2017; 8: 135-145.

[7] Aoshima K. Itai-itai disease: Renal tubular osteomalacia induced by environmental exposure to cadmiumhistorical review and perspectives. Soil Science and Plant Nutrition. 2016; 62: 319-326.

[8] Nishijo M, Nakagawa H, Suwazono Y, Nogawa K, Kido T. Causes of death in patients with Itai-itai disease suffering from severe chronic cadmium poisoning : a nested case - control analysis of a follow-up study in Japan, BMJ Open. 2017; $1-7$.

[9] Tandon SK, Singh S, Prasad S, Khandekar K, Dwivedi VK, Chatterjee M, Mathur N. Reversal of cadmium induced oxidative stress by chelating agent, antioxidant or their combination in rat. Toxicology Letter. 2003; 145(3):2117.

[10] Flora SJS. Structural, chemical and biological aspects of antioxidants for strategies against metal and metalloid exposure. Oxidative Medicine and Cellular Longevity. 2009; 2: 191-206.

[11] Li S, Yan T, Yang JQ Oberley TD, Oberley LW. The role of cellular glutathione peroxidase redox regulation in the suppression of tumor cell growth by manganese superoxide dismutase, Cancer Research. 2000; 60(14): 39273939.

[12] Eybl V, Kotyzová D. Protective effect of manganese in cadmium-induced hepatic oxidative damage, changes in cadmium distribution and trace elements level in mice, Interdisciplinary Toxicology. 2010; 3: 68-72.

[13] Bhattacharya PT, Misra SR, Hussain M. Nutritional Aspects of Essential Trace Elements in Oral Health and Disease: An Extensive Review. Scientifica (Cairo). 2016; 1-12.

[14] Ighodaro OM, Akinloye OA. First line defence antioxidants-superoxide dismutase (SOD), catalase (CAT) and glutathione peroxidase (GPX): Their fundamental role in the entire antioxidant defence grid, Alexandria Journal of Medicine. 2018; 54: 287-293.

[15] Macmillan-Crow LA, Cruthirds DL. Invited review: Manganese superoxide dismutase in disease, Free Radical Research. 2001; 34: 325-336.

[16] Chomchan R, Siripongvutikorn S, Maliyam P, Saibandith B, Puttarak P. Protective effect of selenium-enriched ricegrass juice against cadmium-induced toxicity and DNA damage in HEK293 kidney cells, Foods. 2018; 7 (81): $1-14$.

[17] Mafulul SG, Okoye ZSC. Protective effect of pre-supplementation with selenium on cadmium-induced oxidative damage to some rat tissues, International Journal of Biological and Chemical Sciences. 2012; 6: 1128-1138. 
[18] Asagba SO, Eriyamremu GE, Adaikpoh MA, Ezeoma AE. Levels of lipid peroxidation, superoxide dismutase, and $\mathrm{Na}+/ \mathrm{K}+$ ATPase in some tissues of rats exposed to a Nigerian-like diet and cadmium, Biological Trace Element Research. 2004; 100: 75-86.

[19] Ohkawa H, Ohishi N, Yagi K. Assay for lipid peroxides in animal tissues by thiobarbituric acid reaction, Analytical Biochemistry. 1979; 95: 351-358.

[20] Aebi H. Catalase in Vitro, Methods in Enzymology. 1984; 105: 121-126.

[21] Misra HP, Fridovich I. The role of superoxide anion in the autoxidation of epinephrine and a simple assay for superoxide dismutase, Journal of Biological Chemistry. 1972; 247: 3170-3175.

[22] Paglia DE, Valentine WN. Studies on the quantitative and qualitative characterization of erythrocyte glutathione peroxidase, Journal of Laboratory and Clinical Medicine. 1967; 70(1): 158-169.

[23] Ognjanović BI, Marković SD, Pavlović SZ, Žikić RV, Štajn AŠ, Saičić ZS. Effect of chronic cadmium exposure on antioxidant defense system in some tissues of rats: Protective effect of selenium, Physiological Research. 2008; 57: 403-411.

[24] Eriyamremu GE, Ojimogho SE, Asagba SO, Lolodi O. Changes in brain, liver and kidney lipid peroxidation, antioxidant enzymes and ATPases of rabbits exposed to cadmium ocularly, Journal of Biological Sciences. 2008; 8: 67-73.

[25] Patra RC, Rautray AK, Swarup D. Oxidative stress in lead and cadmium toxicity and its amelioration, Veterinary Medicine International. 2011; 1-9.

[26] Kumar A, Pandey R. Oxidative stress biomarkers of cadmium toxicity in mammalian systems and their distinct ameliorative strategy. 2019; 126-135.

[27] Sharma B, Singh S, Siddiqi NJ. Biomedical implications of heavy metals induced imbalances in redox systems, Biomed Research International. 2014; 1-26.

[28] Berg JM. Metal ions in proteins: Structural and functional roles, Cold Spring Harb. Symposia on Quantitative Biology. 1987; 52: 579-585.

[29] Stohs SJ, Bagchi D. Oxidative mechanisms in the toxicity of metal ions, Free Radical Biology and Medicine. 1995; 18 (2): 321-336.

[30] Prabu SM. Protective effect of Piper betle leaf extract against cadmium-induced oxidative stress and hepatic dysfunction in rats, Saudi Journal of Biological Sciences. 2012; 19: 229-239.

[31] Nasiadek M, Danilewicz M, Klimczak M, Stragierowicz J, Kilanowicz A. Subchronic Exposure to Cadmium Causes Persistent Changes in the Reproductive System in Female Wistar Rats, Oxidative Medicine and Cellular Longevity. 2019; 1-17.

[32] Gaurav D, Preet S, Dua KK. Chronic cadmium toxicity in rats: Treatment with combined administration of vitamins, amino acids, antioxidants and essential metals, Journal of Food and Drug Analysis. 2010; 18(6): 464470.

[33] Ognjanović BI, Marković SD, Dordević NZ, Trbojević IS, Štajn AŠ, Saičić ZS, Cadmium-induced lipid peroxidation and changes in antioxidant defense system in the rat testes: Protective role of coenzyme Q10 and Vitamin E, Reproductive Toxicology. 2010; 29: 191-197.

[34] Ndhlala AR, Ncube B, Van Staden J. Ensuring quality in herbal medicines: Toxic phthalates in plastic-packaged commercial herbal products, South African Journal of Botany. 2012; 82: 60-66.

[35] Hossain MA, Piyatida P, da Silva JAT, Fujita M. Molecular Mechanism of Heavy Metal Toxicity and Tolerance in Plants: Central Role of Glutathione in Detoxification of Reactive Oxygen Species and Methylglyoxal and in Heavy Metal Chelation, Journal of Botany. 2012; 1-37.

[36] Mafulul SG, Joel EB, Barde LA, Lepzem NG. Effect of Pretreatment with Aqueous Leaf Extract of Vitex doniana on Cadmium-Induced Toxicity to Rats, International Journal of Biochemistry Research and Review. 2018 ; 21: 1-10.

[37] Naik SR, Panda VS. Antioxidant and hepatoprotective effects of Ginkgo biloba phytosomes in carbon tetrachloride-induced liver injury in rodents, Liver International. 2007; 27(3): 393-399.

[38] Saka S, Aouacher 0. The Investigation of the Oxidative Stress-Related Parameters in High Doses MethotrexateInduced Albino Wistar Rats, Journal of Bioequivalence and Bioavailability. 2017; 09: 372-376. 
[39] Lobo V, Patil A, Phatak A, Chandra N. Free radicals, antioxidants and functional foods: Impact on human health, Pharmacognosy Review. 2010; 4: 118-126.

[40] Haouem S, El Hani A. Effect of Cadmium on Lipid Peroxidation and on Some Antioxidants in the Liver, Kidneys and Testes of Rats Given Diet Containing Cadmium-polluted Radish Bulbs, Journal of Toxicologic Pathology. 2013; 26(4): 359-364.

[41] El-Missiry MA, Shalaby F. Role of $\beta$-carotene in ameliorating the cadmium-induced oxidative stress in rat brain and testis, Journal of Biochemical and Molecular Toxicology. 2000; 14: 238-243.

[42] Maduka HCC, Okoye ZSC. The effect of Sacoglottis gabonensis stem bark extract, a Nigerian alcoholic beverage additive, on the natural antioxidant defences during 2,4-dinitrophenyl hydrazine-induced membrane peroxidation in vivo. Vascul. Pharmacol. 2002; 39: 21-31. 